\title{
PENGEMBANGAN MEDIA PEMBELAJARAN BERBASIS MULTIMEDIA INTERAKTIF PADA MATA PELAJARAN SIMULASI DIGITAL KELAS X TKJ
}

\author{
Widia Kurniawati $^{1}$, Kholida Ismatulloh ${ }^{2}$, Yosi Nur Kholisho ${ }^{3}$, \\ ${ }_{1,2,3}$ Program Studi Pendidikan Informatika, \\ Fakultas Matematika dan Ilmu Pengetahuan Alam, Universitas Hamzanwadi \\ Email: widiakurniawati64@gmail.com ${ }^{1}$, kholida.ebtaryadi@gmail.com ${ }^{2}$, \\ yosink.peninfo@gmail.com ${ }^{3}$
}

\begin{abstract}
Abstrak
Tujuan dari penelitian ini yaitu (1) untuk mengetahui pengembangan media pembelajaran berbasis multimedia interaktif pada mata pelajaran simulasi digital kelas X TKJ di SMKN 3 Selong; (2) mengetahui kelayakan dari ahli media dan ahli materi terhadap produk media pembelajaran berbasis multimedia interaktif; (3) mengetahui respon siswa terhadap media pembelajaran berbasis multimedia interaktif. Metode penelitian yang digunakan yaitu metode Research and Development $(R \& D)$. Model pengembangan yang digunakan pada penelitian adalah model penelitian dan pengembangan Sugiyono. Pengumpulan data yang digunakan adalah observasi, wawancara, dan angket. Teknik analisis data menggunakan data kualitatif dan kuantitatif. Hasil penelitian menunjukkan bahwa media pembelajaran berbasis multimedia interaktif yang dikembangkan sangat layak untuk digunakan dalam proses pembelajaran. Dari ahli media kelayakan media pembelajaran berbasis multimedia interaktif memperoleh presentase kelayakan dari ahli media sebesar $89 \%$ dengan kriteria sangat layak. Sementara itu dari ahli materi kelayakan materi memperoleh presentase kelayakan dari ahli materi sebesar $91 \%$ dengan kriteria sangat layak. Dari respon siswa kelayakan media pada uji coba produk memperoleh presentase nilai respon siswa sebesar 95\% dengan kriteria sangat tinggi dan pada uji coba pemakaian memperoleh presentase nilai respon siswa sebesar 94\% dengan kriteria sangat tinggi.
\end{abstract}

Kata Kunci: Media Pembelajaran, Multimedia Interaktif, Simulasi Digital

\begin{abstract}
The purpose of this study is (1) to find out the development of interactive multimedia-based learning media on digital simulation subjects of class X TKJ at SMK 3 Selong; (2) knowing the feasibility of media experts and material experts on interactive multimedia-based learning media products; (3) knowing students responses to interactive multimedia-based learning media. The research method used is the Research and Development $(R \& D)$ method. The development model used in the research is Sugiyono's research and development model. Data collection used is observation, interview, and questionnaire. Data analysis techniques use qualitative and quantitative data. The results showed that the interactive multimedia-based learning media developed were very feasible to be used in the learning process. From the feasibility media experts, interactive multimedia-based learning media obtained a feasibility percentage from media experts by $89 \%$ with very decent criteria. Meanwhile, the material feasibility experts obtained a percentage of eligibility from material experts by $91 \%$ with very feasible criteria. From the students response to media feasibility in product trials obtaining a percentage of student response values by $95 \%$ with very high criteria and in the trial of usage obtaining a percentage of student response values by $94 \%$ with very high criteria.
\end{abstract}

Keywords: Learning Media, Interactive Multimedia, Digital Simulation

\section{PENDAHULUAN}

Pendidikan merupakan suatu proses belajar bagi siswa untuk mulai memahami arti pentingnya suatu pendidikan, melalui proses pembelajaran siswa dapat memiliki pengetahuan dan keterampilan yang akan dimiliki dalam dirinya. Pendidikan dimulai dari Prasekolah 
(TK), Sekolah Dasar (SD), Sekolah Menengah Pertama (SMP), Sekolah Menengah Atas atau Kejuruan (SMA/SMK), dan Perguruan Tinggi.

Pendidikan adalah suatu proses dalam rangka mempengaruhi peserta didik supaya mampu menyesuaikan diri sebaik mungkin dengan lingkungannya, dan dengan demikian akan menimbulkan perubahan dalam dirinya yang memungkinkannya untuk berfungsi secara memadai dalam kehidupan masyarakat (Hamalik, 2015:3).

Peran guru dalam dunia pendidikan sangat penting karena menjadi seorang pengajar, motivator, dan pasilitator bagi muridnya. Sebelum melakukakn proses pembelajaran di dalam kelas seorang guru harus terlebih dahulu merencanakan proses pembelajaran yang dilakukan seperti membuat program tahunan, program semester, pemetaan, RPP, dan silabus. Salah satu hal dalam proses pembelajaran yang terpenting bagi seorang guru adalah mengembangkan media pembelajaran. Saat ini sangat dibutuhkan bagi sekolah-sekolah yang mata pelajarannya bersifat praktikum contohnya SMK, akan tetapi keberadaan media pembelajaran di SMK masih sangat kurang misalnya, masih kurangnya media pembelajaran berbasis multimedia interaktif. Kebutuhan pengembangan media pembelajaran dirasa sangat penting khususnya bagi SMK-SMK yang terdapat di provinsi NTB.

Berdasarkan observasi yang dilakukan pada siswa kelas X TKJ di SMKN 3 Selong pada mata pelajaran Simulasi Digital dapat dilihat bahwa minat belajar dan motivasi belajar siswa masih kurang karena guru belum menciptakan suasana pembelajaran yang menyenangkan dan menarik. Sedangkan berdasarkan wawancara yang dilakukan dengan guru mata pelajaran simulasi digital di SMKN 3 Selong mengatakan bahwa metode pembelajaran yang digunakan dalam proses pembelajaran yaitu metode pembelajaran konvensional dimana metode ini hanya menggunakan ceramah sehingga proses pembelajaran terlalu menoton dan media pembelajaran yang digunakan masih menggunakan media pembelajaran power point dan video, hal tersebut menyebabkan siswa kurang memahami materi pembelajaran yang disampaikan oleh guru. Guru harus merencanakan media pembelajaran yang tepat agar siswa lebih fokus dan aktif dalam proses pembelajaran.

Mengatasi permasalahan tersebut diperlukan media pembelajaran yang lebih menarik, agar siswa merasa senang dan tertarik dalam mengikuti proses pembelajaran dan dapat menerima materi pelajaran dengan maksimal serta dapat membangkitkan semangat siswa untuk mengikuti proses belajar di dalam kelas. Media pembelajaran yang akan digunakan adalah media pembelajaran berbasis Multimedia Interaktif.

Media Pembelajaran adalah media yang membawa pesan-pesan atau informasi yang bertujuan intruksional atau mengandung maksud-maksud pengajaran (Arsyad, 2011:4). Menurut Gagne dan Briggs dalam Arsyad (2011:4) secara implisit mengatakan bahwa media pembelajaran meliputi alat yang secara fisik di gunakan untuk menyampaikan isi materi pengajaran, yang terdiri dari antara lain, buku, tape recorder, kaset, video camera, video recorder, film, slide (gambar bingkai), foto, gambar, grafik, televisi, dan komputer. Sementara itu beberapa peneliti telah mengembangkan media pembelajaran berbasis multimedia interaktif, pada mata pelajaran yang berbeda-beda (Usyanti dan Susanti, 2015; Yasa, Ariawan, dan Sutaya, 2017; Yuliandari dan Wahjudi, 2014).

Berdasarkan uraian diatas peneliti tertarik melakukan penelitian dengan mengembangkan media pembelajaran berbasis multimedia interaktif pada mata pelajaran simulasi sigital kelas X TKJ di SMKN 3 Selong.

\section{METODE}

Model pengembangan dalam pengembangan media pembelajaran berbasis Multimedia Interaktif menggunakan penelitian dan pengembangan (Research and Development) yaitu 
dengan menggunakan model Sugiyono. Metode penelitian dan pengembangan atau dalam bahasa inggrisnya Research and Development adalah metode penelitian yang digunakan untuk menghasilkan produk tertentu, dan menguji keefektifan produk terdebut (Sugiyono, 2012:407)

Model dalam penelitian dan pengembangan yang digunakan oleh peneliti dalam penelitian ini adalah model penelitian dan pengembangan Sugiyono. Dalam melakukan pengembangan media pembelajaran ada 10 langkah-langkah pelaksanaan penelitian dan pengembangan yaitu potensi dan masalah, pengumpulan data, desain produk, validasi desain, revisi desain, uji coba produk, revisi produk, uji coba pemakaian, revisi produk, produksi masal (Sugiyono, 2012:408). Prosedur pengembangan media pembelajaran berbasis multimedia interaktif terdiri dari 10 tahap.

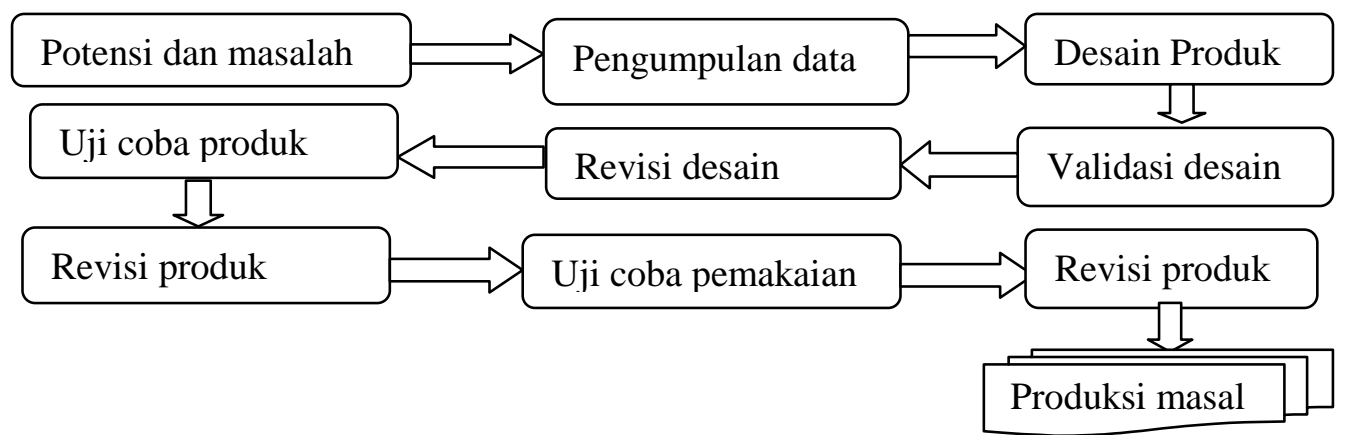

Gambar 1. Prosedur penelitian dan pengembangan (Sugiyono)

Subjek penelitian yaitu kelas X TKJ yang terdiri dari 2 kelas yaitu, TKJ 1 dan TKJ 2 . Subjek penelitian yang akan diambil yaitu kelas X TKJ 2. Jenis data yang digunakan yaitu data kulitatif dan kuantitatif. Dimana data kualitatif merupakan data tentang proses pengembangan media pembelajaran yang berupa kritik, saran atau masukan yang diberikan oleh ahli media, ahli materi, dan siswa. Sedangkan data kuantitatif merupakan data pokok yang diperoleh melalui angket yang berupa data penilaian kelayakan tentang media pembelajaran dari ahli media, ahli materi, dan dan data pendapat atau respon siswa mengenai produk yang telah dibuat.

Instrumen pengumpulan data yaitu, Observasi, wawancara, dan angket (kuesioner). Teknik analisis data yang digunakan yaitu data kualitatif dan data kuantitatif. Data kualitatif berupa saran atau masukan yang diberikan oleh ahli media, ahli materi, dan data hasil respon siswa terhadap produk yang dikembangkan. Data kuantitatif di peroleh dari angket penilaian kualitas produk yang diberikan kepada ahli media, ahli materi, dan siswa.

Uji validitas instrumen menggunakan validitas konstruk, diamana validitas konstruk digunakan untuk mengukur sejauh mana suatu instrumen mengukur konsep dari suatu teori yaitu menjadi dasar penyusunan instrumen (Eko Putro Widoyoko, 2017:129). Uji validitas instrumen menggunakan rumus korelasi product moment yang digunakan untuk menghasilkan data yang valid atau tidak valid. Uji reliabilitas menggunakan rumus alpha cronbach. Rumus alpha cronbach digunakan karena penelitian ini menggunakan angket dengan skala likert.

\section{HASIL DAN PEMBAHASAN Hasil Penelitian}

Media yang dikembangkan dalam penelitian ini adalah media pembelajaran berbasis multimedia interaktif pada mata pelajaran simulasi digital kelas X TKJ di SMKN 3 Selong. 
Pengembangan media dilakukan dengan menggunakan model penelitian dan pengembangan atau Research and Development $(R \& D)$ yaitu menggunakan model penelitian sugiyono dengan langkah-langkah pelaksanaan penelitian dan pengembangan sebanyak 10 tahapan yaitu, potensi dan masalah, pengumpulan data, desain produk, validasi desain, revisi desain, uji coba produk, revisi produk, uji coba pemakaian, revisi produk, produksi masal. Berikut akan dijelaskan tentang hasil yang telah di dapat setelah melakukan pengembangan media pembelajaran berbasis multimedia interaktif pada mata pelajaran simulasi digital kelas X TKJ di SMKN 3 Selong.

Pengembangan media pembelajaran berbasis multimedia interaktif pada mata pelajaran simulasi digital kelas X TKJ di SMKN 3 Selong dapat dilihat pada gamabar-gambar dibawah ini.

1. Tampilan awal

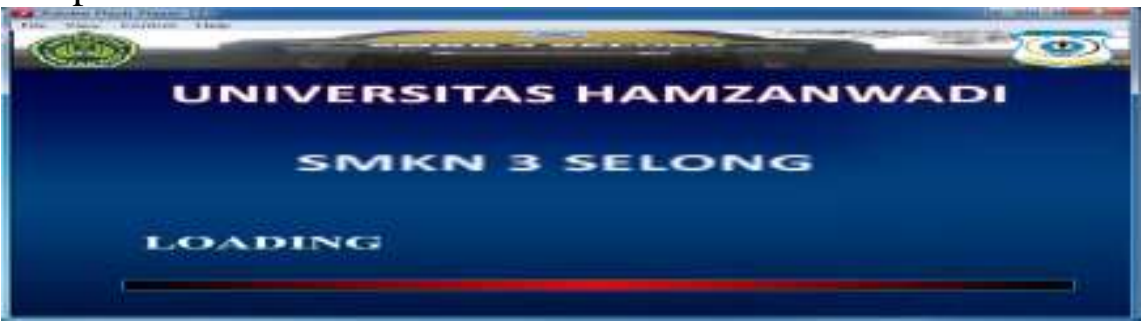

Gambar 2. Tampilan awal

2. Tampilan masuk

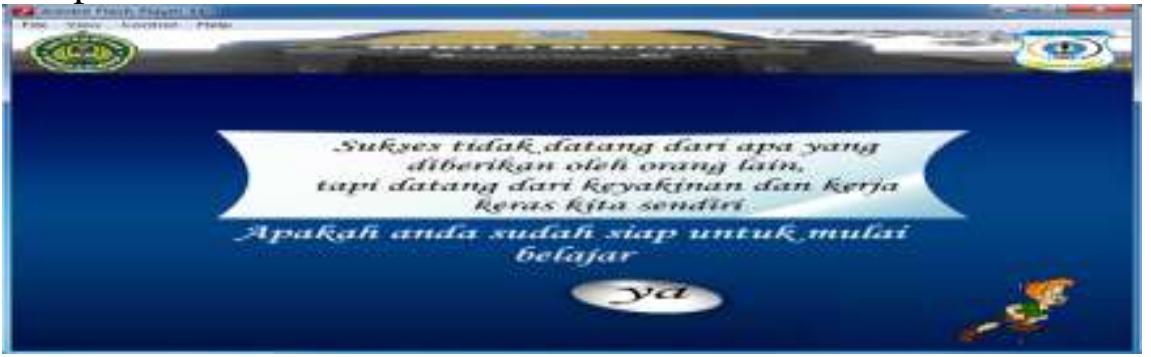

Gambar 3. Tampilan masuk

3. Menu

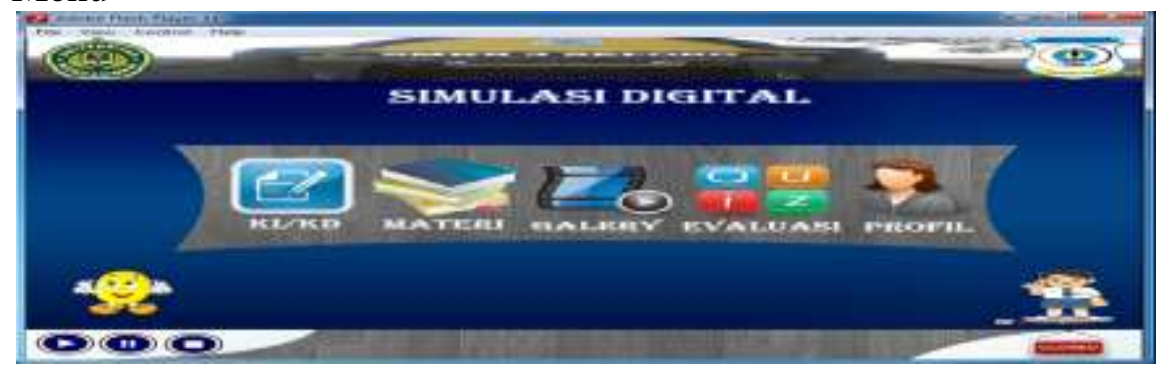

Gambar 4. Menu 


\section{e-ISSN 2549-7472}

Volume 2, Nomor 2, Desember 2018

4. $\mathrm{KI} / \mathrm{KD}$

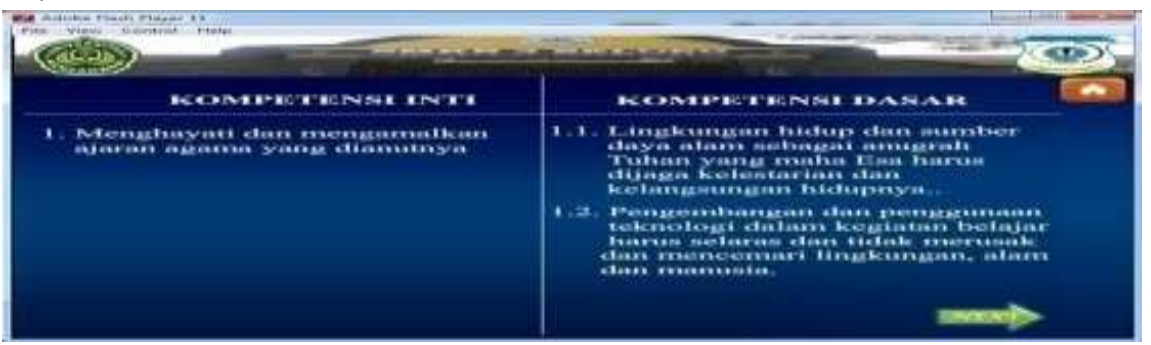

Gambar 5. KI/KD

5. Materi

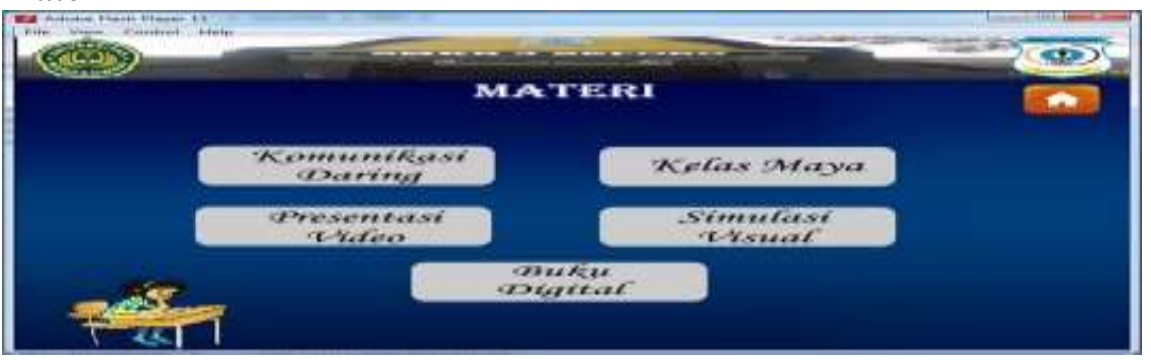

Gambar 6. Materi

6. Galeri

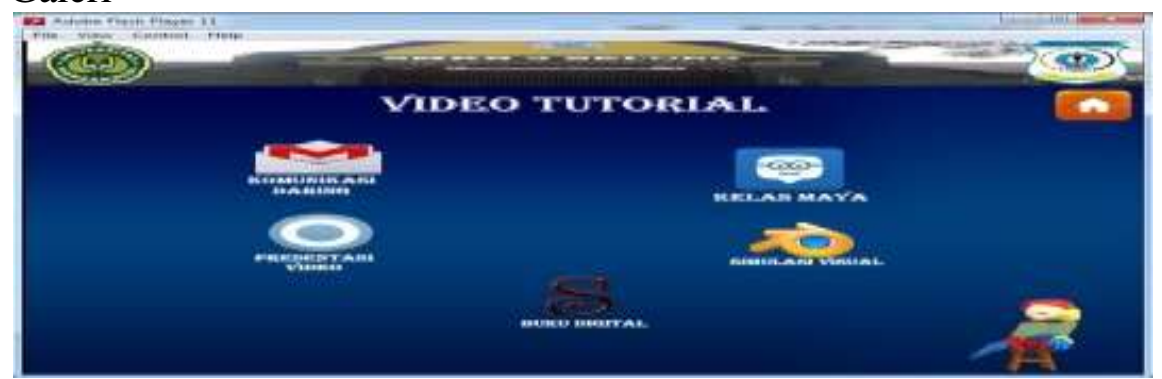

Gambar 7. Galeri

7. Evaluasi

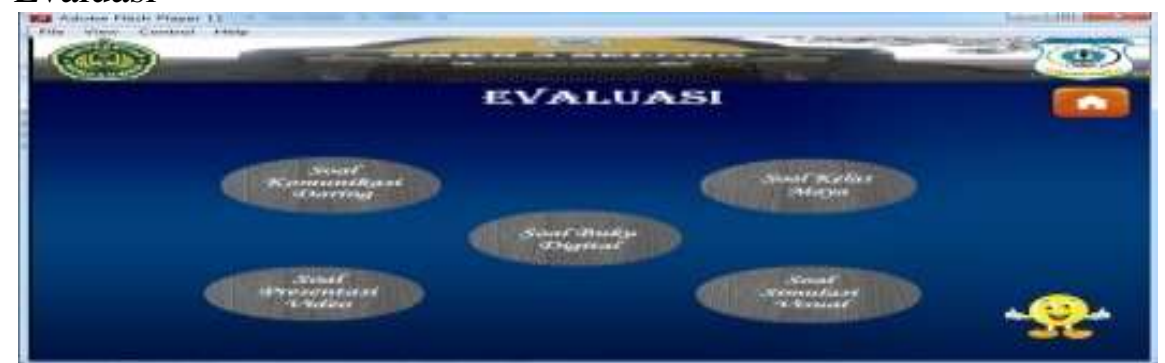

Gambar 8. Evaluasi 
8. Profil

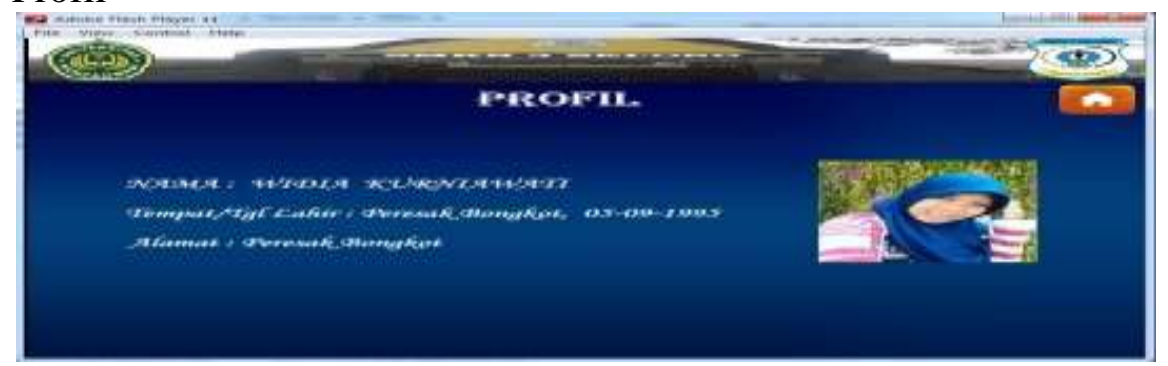

Gambar 9. Profil

9. Keluar

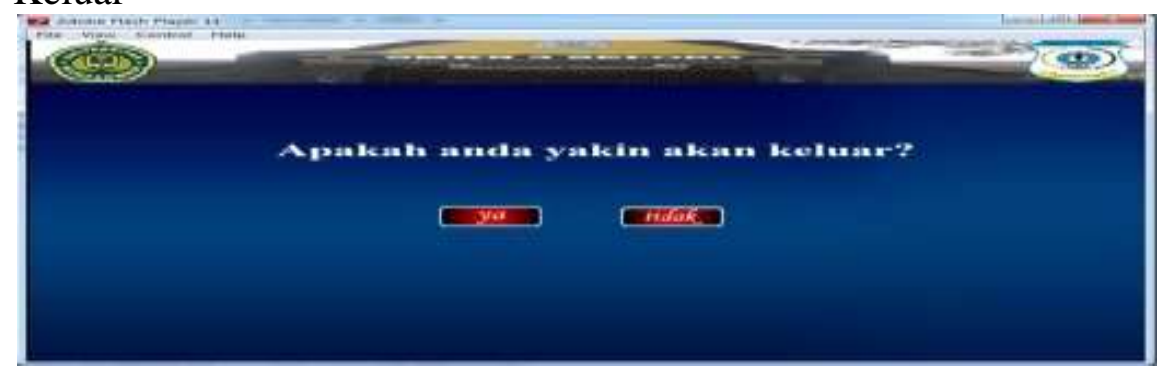

Gambar 10. Keluar

Kelayakan media dari penilaian ahli media terhadap 4 aspek penilaian yaitu desain media pembelajaran berbasis multimedia interaktif, aspek navigasi, aspek keterbacaan, dan pemrograman yang terdiri dari 16 indikator dapat dilihat hasil presentase kelayakan ahli media terhadap masing-masing aspek penilaian.

Tabel 1. Hasil Presentase kelayakan ahli media

\begin{tabular}{clcc}
\hline No & \multicolumn{1}{c}{ Aspek } & Presentase & Kategori \\
\hline 1 & Desain media pembelajaran & $78 \%$ & Sangat Layak \\
& berbasis multimedia interaktif & & \\
2 & Aspek navigasi & $95 \%$ & Sangat Layak \\
3 & Aspek Keterbacaan & $94 \%$ & Sangat Layak \\
4 & Pemrograman & $97 \%$ & Sangat Layak \\
\hline & Rata-rata Presentase & $\mathbf{8 9 \%}$ & Sangat Layak \\
\hline
\end{tabular}

Berdasarkan tabel 1. diatas dapat dilihat bahwa presentase kelayakan dari ahli media terhadap 4 aspek penilaian dengan rata-rata presentase kelayakan media sebesar $89 \%$ dengan kriteria sangat layak. Kelayakan materi dari penilaian ahli materi terhadap 5 aspek penilaian yaitu tujuan pembelajaran, aspek materi, aspek keterbacaan, aspek soal, aspek bahasa yang terdiri dari 11 indikator dapat dilihat hasil presentase kelayakan ahli materi terhadap masingmasing aspek penilaian.

Tabel 2. Hasil presentase kelayakan ahli materi

\begin{tabular}{llcc}
\hline No & \multicolumn{1}{c}{ Aspek } & Presentase & Kategori \\
\hline 1 & Tujuan Pembelajaran & $85 \%$ & Sangat Layak \\
2 & Aspek materi & $85 \%$ & Sangat Layak \\
3 & Aspek keterbacaan & $100 \%$ & Sangat Layak \\
4 & Aspek soal & $100 \%$ & Sangat Layak \\
5 & Aspek bahasa & $90 \%$ & Sangat Layak \\
\hline & Rata-rata presentase & $\mathbf{9 1 \%}$ & Sangat Layak \\
\hline
\end{tabular}


Berdasarkan tabel 2. diatas dapat dilihat bahwa presentase kelayakan dari ahli materi terhadap 5 aspek penilaian mendapatkan nilai presentase kelayakan media sebesar $91 \%$ dengan kriteria sangat layak. Respon Siswa terhadap media pembelajaran berbasis multimedia interaktif dapat dilihat pada tabel dibawah ini

\begin{tabular}{clc}
\multicolumn{2}{c}{ Tabel 3. Hasil Respon 10 Orang Siswa } \\
\hline No & \multicolumn{1}{c}{ Aspek } & Rata-rata Presentase \\
\hline 1 & Desain media & $94 \%$ \\
2 & Penggunaan media pembelajaran & $93 \%$ \\
3 & Aspek navigasi & $96 \%$ \\
4 & Aspek keterbacaan & $96 \%$ \\
\hline Total Presentase Nilai Respon Siswa & $\mathbf{9 5 \%}$
\end{tabular}

Berdasarkan tabel 3. diatas dapat dilihat total presentase nilai respon siswa sebesar $95 \%$ dengan kriteria sangat tinggi. Selanjutnya respon 28 siswa terhadap produk media pembelajaran berbasis multimedia interaktif dapat dilihat pada tabel berikut.

Tabel 4. Hasil Respon 28 orang siswa

\begin{tabular}{clc}
\hline No & \multicolumn{1}{c}{ Aspek } & Rata-rata Presentase \\
\hline 1 & Desain media & $95 \%$ \\
2 & Penggunaan media pembelajaran & $93 \%$ \\
3 & Aspek navigasi & $94 \%$ \\
4 & Aspek keterbacaan & $95 \%$ \\
\hline Total Presentase Nilai Respon Siswa & $\mathbf{9 4 \%}$ \\
\hline
\end{tabular}

Berdasarkan tabel 4. Diatas dapat dilihat total presentase nilai respon siswa sebesar 94\% dengan kriteria sangat tinggi.

\section{Pembahasan}

Pengembangan media pembelajaran berbasis multimedia interaktif menggunakan model penelitian dan pengembangan atau Research and Dvelopment $(R \& D)$ menggunakan model penelitian Sugiyono dengan langkah-langkah pelaksanaan penelitian dan pengembangan sebanyak 10 tahapan yaitu: potensi dan masalah, pengumpulan data, desain produk, validasi desain, revisi desain, uji coba produk, revisi produk, uji coba pemakaian, revisi produk, produksi masal. Media pembelajaran yang dikembangkan berisi tampilan awal, tampilan masuk, menu, KI/KD, materi, galeri, evaluasi, creator, audio, dan tampilan keluar.

Ahli media memberikan penilaian dengan jumlah skor 131 dan presentase yang diperoleh dari masing-masing aspek yang terdiri dari 4 aspek yaitu aspek desain media pembelajaran berbasis multimedia interaktif memperoleh nilai sebesar $78 \%$ dengan indikator yaitu kualitas media, ketepatan pemilihan warna background dengan teks pada media, ukuran media pembelajaran, kemenarikan animasi yang digunakan, daya dukung musik pada media, dan kemenarikan media yang digunakan. Dari 6 indikator pada aspek desain media pembelajaran berbasis multimedia interaktif tersebut diketahui bahwa desain yang digunakan dalam media sudah menarik. Aspek navigasi memperoleh nilai sebesar 95\% dengan indikator yaitu kualitas tampilan tombol navigasi, kemenarikan gambar yang digunakan sebagai tombol navigasi, keberfungsian tombol-tombol navigasi yang digunakan dalam media, dan ketepatan peletakan tombol. Dari 4 indikator pada aspek navigasi dapat dilihat bahwa tombol navigasi sudah cocok untuk digunakan dalam media. Aspek keterbacaan memperoleh nilai sebesar 94\% dengan indikator yaitu kejelasan materi yang disajikan dalam media, dan 
kemudahan dalam membaca teks dalam media. Dari 2 indikator pada aspek keterbacaan tersebut diketahui bahwa teks yang dimasukkan dalam media sudah jelas. Aspek pemrograman memperoleh nilai sebesar 97\% dengan indikator yaitu kecepatan program, kemenarikan media, kemudahan dalam penggunaan media, dan ketepatan memilih menumenu yang disajikan. Dari 4 indikator pada aspek pemrograman tersebut diketahui bahwa menu-menu dalam media sudah bagus. Sehingga dari 4 aspek yang dinilai dapat diketahui bahwa total rata-rata presentase kelayakan media dari ahli media sebesar $89 \%$ dengan kriteria sangat layak.

Ahli materi memberikan penilaian dengan jumlah skor 96 dan presentase yang diperoleh dari masing-masing aspek yang terdiri dari 5 aspek yaitu, tujuan pembelajaran memperoleh nilai sebesar $85 \%$ dengan indikator yaitu kesesuaian materi dengan KI/KD, kemudahan memahami materi. Dari 2 indikator pada tujuan pembelajaran ternyata sudah sesuai dengan $\mathrm{KI} / \mathrm{KD}$. Aspek materi memperoleh nilai sebesar $85 \%$ dengan indikator yaitu kejelasan penyajian materi dalam media, kemudahan memahami materi dalam media, kesesuian materi dalam media, dan kesesuaian video tutorial yang dimasukan dengan materi. Dari 4 indikator pada aspek materi tersebut dapat diketahui bahwa materi yang disajikan dalam media sudah sesuai dengan materi yang diajarkan. Aspek keterbacaan memperoleh nilai sebesar 100\% dengan indikator yaitu kemudahan dalam membaca teks dalam media, dan kejelasan dalam melihat teks. Dari 2 indikator pada aspek keterbacaan tersebut dapat diketahui bahwa teks yang dimasukkan dalam media sudah sangat jelas. Aspek soal memperoleh nilai sebesar $100 \%$ dengan indikator yaitu kejelasan soal yang diberikan dalam media, dan kesesuaian soal dengan teori. Dari 2 indikator pada aspek soal tersebut diketahui bahwa soal-soal yang dimasukkan dalam media sudah sesuai dengan isi materi. Pada aspek bahasa memperoleh nilai sebesar 90\% dengan indikator yaitu keefektifan bahasa yang digunakan. Dari 1 indikator pada aspek bahasa tersebut diketahui bahwa bahasa-bahasa yang digunakan dalam media sudah sangat efektif. Sehingga dari 5 aspek yang dinilai dapat diketahui bahwa total rata-rata presentase kelayakan dari ahli materi sebesar $91 \%$ dengan kriteria sangat layak.

Siswa memberikan penilaian dengan jumlah indikator sebanyak 20. Penilaian pada uji coba produk dilakukan pada 10 siswa dengan jumlah skor 942 dan yang terdiri dari 4 aspek yaitu desain media memperoleh nilai sebesar 94\% dengan indikator yaitu kualitas tampilan media, ketepatan pemilihan warna background dengan teks pada media, kemenarikan animasi yang digunakan, daya dukung musik pada media, kemenarikan media yang digunakan, dan kesesuaian dalam memilih ukuran huruf. Dari 6 indikator pada desain media tersebut diketahui bahwa desain media sudah sesuai dengan keinginan siswa. Penggunaan media pembelajaran memperoleh nilai sebesar 93\% dengan indikator yaitu kejelasan penyajian materi dalam media, kemudahan memahami materi dalam media, kesesuaian materi dalam media, keefektifan bahasa yang digunakan, kesesuaian video tutorial yang dimasukkan di media dengan materi, kebebasan memilih menu-menu, kejelasan soal yang diberikan dalam media, dan kesesuaian soal dengan teori. Dari 8 indikator pada penggunaan media pembelajaran tersebut diketahui bahwa media yang dibuat sudah sesuai dengan kebutuhan siswa. Aspek navigasi memperoleh nilai sebesar 96\% dengan indikator yaitu kualitas tampilan tombol navigasi, kemenarikan gambar yang digunakan sebagai tombol navigasi, keberfungsian tombol-tombol navigasi yang digunakan dalam media, dan ketepatan peletakkan tombol pada media. Dari 4 indikator pada aspek naviagasi tersebut diketahui bahwa tombol navigasi yang dgunakan dalam media sudah bagus. Pada aspek keterbacaan memperoleh nilai sebesar $96 \%$ dengan indikator yaitu kemudahan dalam membaca teks dalam media, dan kejelasan dalam melihat teks. Dari 2 indikator pada aspek keterbacaan tersebut diketahui bahwa teks dalam media dapat dilihat dengan jelas oleh siswa. Sehingga 
dari ke 4 aspek yang dinilai dapat diketahui total presentase nilai respon siswa sebesar 95\% dengan kriteria sangat tinggi. Penilaian pada uji coba pemakaian yang dilakukan pada 28 siswa dengan jumlah skor 2.625 dan yang terdiri dari 4 aspek yaitu desain media memperoleh nilai sebesar 95\% dengan indikator yaitu kualitas tampilan media, ketepatan pemilihan warna background dengan teks pada media, kemenarikan animasi yang digunakan, daya dukung musik pada media, kemenarikan media yang digunakan, dan kesesuaian dalam memilih ukuran huruf. Dari 6 indikator pada desain media tersebut diketahui bahwa desain media sudah sesuai dengan keinginan siswa. Penggunaan media pembelajaran memperoleh nilai sebesar 93\% dengan indikator yaitu kejelasan penyajian materi dalam media, kemudahan memahami materi dalam media, kesesuaian materi dalam media, keefektifan bahasa yang digunakan, kesesuaian video tutorial yang dimasukkan di media dengan materi, kebebasan memilih menu-menu, kejelasan soal yang diberikan dalam media, dan kesesuaian soal dengan teori. Dari 8 indikator pada penggunaan media pembelajaran tersebut diketahui bahwa media yang dibuat sudah sesuai dengan kebutuhan siswa. Aspek navigasi memperoleh nilai sebesar 94\% dengan indikator yaitu kualitas tampilan tombol navigasi, kemenarikan gambar yang digunakan sebagai tombol navigasi, keberfungsian tombol-tombol navigasi yang digunakan dalam media, dan ketepatan peletakkan tombol pada media. Dari 4 indikator pada aspek naviagasi tersebut diketahui bahwa tombol navigasi yang dgunakan dalam media sudah bagus. Pada aspek keterbacaan memperoleh nilai sebesar 95\% dengan indikator yaitu kemudahan dalam membaca teks dalam media, dan kejelasan dalam melihat teks. Dari 2 indikator pada aspek keterbacaan tersebut diketahui bahwa teks dalam media dapat dilihat dengan jelas oleh siswa. Sehingga dari ke 4 aspek yang dinilai dapat diketahui total presentase nilai respon siswa sebesar 94\% dengan kriteria sangat tinggi.

\section{SIMPULAN}

Pengembangan media pembelajaran berbasis multimedia interaktif pada mata pelajaran simulasi digital kelas X TKJ di SMKN 3 Selong menggunakan model penelitian Sugiyono dengan langkah-langkah pelaksanaan dan pengembangan sebanyak 10 tahapan. Hasil kelayakan media dari ahli media mendapat total presentase kelayakan media sebesar $89 \%$ dengan kriteria sangat layak. Sedangkan kelayakan media dari ahli materi mendapat total presentase kelayakan sebesar 91\% dengan kriteria sangat layak. Respon siswa pada uji coba produk memberikan total presentase nilai respon siswa sebesar 95\% dengan kriteria sangat tinggi. Sedangkan respon siswa pada uji coba pemakaian memberikan total presentase nilai respon siswa sebesar $94 \%$ dengan kriteria sangat tinggi.

\section{REFERENSI}

Arsyad, Azhar. (2011). Media Pembelajaran. Jakarta: Raja Grafindo Persada.

Hamalik, Oemar. (2015). Kurikulum dan Pembelajaran. Jakarta: Bumi Aksara.

Yasa, Ariawan, dan Sutaya. (2017). Pengembangan Media Pembelajaran Interaktif Berbasis Adobe Flash Pada Mata Pelajaran Prakarya Dan Kewirausahaan Materi Elektro Listrik Untuk Kelas XI MIPA Dan IPS Di SMA Negeri 3 Singaraja. Jurnal Pendidikan Teknologi dan Kejuruan. 14(2), 199-209

Usyanti dan Susanti. (2015). Pengembangan Media Pembelajaran Akutansi Berbasis Multimedia Interaktif Pada Materi Rekonsiliasi Bank Untuk Kelas XI Akutansi SMK Negeri 1 Lamongan. Jurnal Pengembangan Media Pembelajaran Multimedia Interaktif. 3(3), 1-9. 
e-ISSN 2549-7472

Volume 2, Nomor 2, Desember 2018

Yuliandari dan Wahjudi. (2014). Pengembangan Media Pembelajaran Berbasis Multimedia Interaktif Pada Mata Pelajaran Ekonomi Materi Jurnal Penyesuaian Perusahaan Jasa. Jurnal Pendidikan Akutansi (JPAK). 2(2), 1-9.

Sugiyono. (2012). Metode Penelitian Pendidikan (Pendekatan Kuantitatif, Kualitatif, dan $R \& D)$. Bandung: Alfabeta

Widoyoko, Eko Putro. (2017). Evaluasi Program Pembelajaran (Panduan Praktis bagi Pendidik dan Calon Pendidik). Yogyakarta: Pustaka Pelajar. 